\title{
ANALISIS KUALITAS MAKANAN KARYAWAN YANG DISAJIKAN DI THE AXANA HOTEL PADANG
}

\author{
Lia Ade Ema Safitri ${ }^{1}$, Lise Asnur ${ }^{2}$ \\ Universitas Negeri Padang \\ e-mail: liaade309@gmail.com, lise.asnur@fpp.unp.ac.id
}

\begin{abstract}
Abstrak
Penelitian ini berawal dari hasil penelitian sebelumnya yang mana terdapat masalah mengenai tidak adanya konsistensi pada daftar menu yang telah dibuat, dan presentasi dari makanan tersebut tidak menarik, terlihat pucat dan tidak berwarna, dan tidak bervariasi, dan makanan pun tidak terlihat fresh lagi dan penyajian makanannya pun berantakan/tidak disusun rapi. Tidak adanya garnish dan variasi warna pada makanan tersebut. Untuk melanjutkan masalah dimana masih terdapatnya masalah-masalah yang berkenaan mengenai kualitas makanan karyawan di The Axana Hotel Padang. Penelitian ini bertujuan untuk menganalisis kualitas makanan karyawan yang disajikan di The Axana Hotel Padang. Jenis penelitian ini adalah deskriptif kuantitatif. Populasi dalam penelitian ini adalah seluruh karyawan yang ada di The Axana Hotel Padang. Teknik pengambilan sample yang digunakan adalah probability sampling. Jumlah sampel pada penelitian ini berjumlah 60 orang. Teknik pengumpulan data dilakukan dengan cara penyebaran angket (kuesioner)dengan menggunakan skala likertyang telah teruji validitas dan reliabilitasnya. Selanjutnya data dianalisis melalui tabulasi data dan deskriptif data menggunakan persentase. Berdasarkan penelitian yang telah dilakukan, diperoleh hasil bahwa kualitas makanan karyawan di The Axana Hotel Padang berada pada kategori cukup dengan persentase $60 \%$.
\end{abstract}

Kata kunci: Kualitas Makanan, The Axana Hotel Padang

\begin{abstract}
This study originated from the results of previous studies where there was a problem regarding the absence of consistency in the menu lists that had been made, and the presentation of the food was unattractive, looked pale and colorless, and did not vary, and the food did not look fresh anymore and the food presentation also messy/not neatly arranged. The absence of garnishes and color variations in these foods. To continue the problem where there are still problems regarding the food quality of employees at The Axana Hotel Padang. This study aims to analyze the quality of employee food served at The Axana Hotel Padang. This research is descriptive quantitative. The population was all employees at The Axana Hotel Padang. The sampling technique used is probability sampling. The number of samples in this study amounted to 60 people. The data collection technique was carried out by distributing questionnaires using a Likert scale that had been tested for validity and reliability. Furthermore, the data were analyzed through data tabulation and descriptive data using percentages. Based on the research that has been done, it is found that the food quality of employees at The Axana Hotel Padang is in a sufficient category $60 \%$.
\end{abstract}

Keywords: Food Quality, The Axana Hotel Padang 


\section{Pendahuluan}

Salah Perkembangan pariwisata di era globalisasi saat ini memberikan kemajuan ekonomi yang besar bagi setiap negara dengan destinasi wisata didunia. Adapun perkembangan pariwisata yang semakin maju menuntut adanya penyediaan akomodasi yang memadai. Hal ini terlihat dari banyaknya muncul jasa penginapan ataupun hotel yang dibangun untuk pemenuhan kebutuhan tersebut, termasuk semakin pesatnya perkembangan hotel di indonesia salah satunya yaitu Kota Padang.

Perusahaan hotel adalah salah satu bentuk perdagangan jasa yang menyediakan jasa penginapan dan jasa pelayanan lainnya untuk memenuhi kebutuhan wisatawan, seperti penyediaan makanan, minuman, spa dan fasilitas rekreasi, salah satunya adalah The Axana Hotel Padang. The Axana Hotel Padang memiliki beberapa departemen sama seperti hotel berbintang pada umumnya dalam menjalankan operasional sehari-hari. Total karyawan yang dimiliki oleh The Axana Hotel Padang adalah 61 orang.

Karyawan Hotel The Axana merupakan tenaga penggerak yang paling penting bagi hotel sehingga diperlukan kesehatan baik itu jasmani maupun rohani, karena sebuah hotel tidak akan berjalan dengan baik jika karyawan memiliki kesehatan yang tidak baik sehingga hotel harus bertanggung jawab atas kesehatan para karyawannya. Oleh sebab itu langkah awal bagi hotel untuk menjaga kesehatan karyawannya adalah dengan menyediakan makanan yang menggugah selera sehingga karyawan tidak akan bosan terhadap makanan yang disediakan oleh hotel dan yang pastinya harus menjaga kualitas makanan yang akan dikonsumsi oleh karyawan.

Berdasarkan hasil wawancara peneliti dilapangan pada tanggal 17 Maret 2020 kepada karyawan Human Resources di The Axana Hotel Padang, mengatakan kualitas dari makanan yang disajikan di kantin karyawan kurang memuaskan seperti, makanan tersebut tidak menarik , terlihat pucat dan tidak berwarna, dan tidak bervariasi, dan makanan pun tidak terlihat fresh lagi dan penyajian makanannya pun berantakan/tidak disusun rapi dan tidak adanya pengontrolan terhadap porsi makanan karyawan tersebut. Berdasarkan uraian permasalahan diatas, penulis mengangkat penelitian ini dengan judul "Analisis Kualitas Makanan Karyawan yang Disajikan di The Axana Hotel Padang".

\section{Metode}

Jenis penelitian ini adalah deskriptif kuantitatif. Populasi dalam penelitian ini adalah seluruh karyawan yang ada di The Axana Hotel Padang. Teknik pengambilan sample yang digunakan adalah probability sampling. Jumlah sampel pada penelitian ini berjumlah 60 orang. Teknik analisis data dilakukan dengan menggunakan program komputer SPSSversi 20.00. Teknik pengumpulan data dilakukan dengan cara penyebaran angket (kuesioner) dengan menggunakan skala likert, kemudian diolah. Dengan cara menyajikan data ke dalam tabel distribusi frekuensi, menghitung nilai rata-rata, kemudian di klasifikasikan ke dalam beberapa kategori yaitu sangat baik, baik, cukup, buruk dan sangat buruk.

\section{Hasil dan Pembahasan}

a. Setelah Analisis Deskriptif Frekuensi Variabel Kualitas Makanan

Tabel 1. Distribusi Frekuensi Variabel Kualitas Makanan

\begin{tabular}{|c|c|c|c|}
\hline Kategori & Skor & Frekuensi & Persentase (\%) \\
\hline Sangat Baik & $\geq 120$ & 0 & $0 \%$ \\
\hline Baik & $100 \leq 120$ & 20 & $33,33 \%$ \\
\hline Cukup & $80 \leq 100$ & 36 & $60 \%$ \\
\hline Buruk & $60 \leq 80$ & 4 & $6,67 \%$ \\
\hline Sangat Buruk & $<60$ & 0 & $0 \%$ \\
\hline \multicolumn{2}{|c|}{ Total } & 60 & $100 \%$ \\
\hline
\end{tabular}


Jurnal Bosaparis: Pendidikan Kesejahteraan Keluarga

Volume 11, Nomor 1, Maret 2020

Berdasarkan Tabel diatas dapat dijelaskan bahwa 60 responden untuk variabel kualitas makanan menunjukan kategori sangat baik sebanyak $0 \%$, kategori baik sebanyak 33,33\%, kategori cukup sebanyak $60 \%$, kategori buruk sebanyak 6,67\% dan kategori sangat buruk $0 \%$. Berdasarkan klasifikasi skor persentase tertinggi berada pada rentang $80 \leq 100$ dengan persentase $60 \%$ yang menunjukan kategori cukup. berikut:

Selanjutnya variabel kualitas makanan diklasifikasikan masing-masing indikator, sebagai

Tabel 2. Distribusi Frekuensi Indikator Freshness

\begin{tabular}{cccc}
\hline Kategori & Skor & Frekuensi & Persentase (\%) \\
\hline Sangat Baik & $\geq 48$ & 0 & $0 \%$ \\
Baik & $40 \leq 48$ & 25 & $41,67 \%$ \\
Cukup & $\mathbf{3 2 \leq 4 0}$ & $\mathbf{3 2}$ & $\mathbf{5 3 , 3 3 \%}$ \\
Buruk & $24 \leq 32$ & 3 & $5 \%$ \\
Sangat Buruk & $<24$ & 0 & $0 \%$ \\
\hline Total & & $\mathbf{6 0}$ & $\mathbf{1 0 0 \%}$ \\
\hline
\end{tabular}

Berdasarkan Tabel diatas dapat dijelaskan bahwa 60 responden untuk variabel freshness menunjukan kategori sangat baik sebanyak 0\%, kategori baik sebanyak 41,67\%, kategori cukup sebanyak 53,33\%, kategori buruk sebanyak 5\% dan kategori sangat buruk $0 \%$. Berdasarkan klasifikasi skor persentase tertinggi berada pada rentang $32 \leq 40$ dengan persentase $50 \%$ yang menunjukan kategori cukup.

Tabel 3. Distribusi Frekuensi Indikator Presentation

\begin{tabular}{cccc}
\hline Kategori & Skor & Frekuensi & Persentase (\%) \\
\hline Sangat Baik & $\geq 27,9$ & 0 & $0 \%$ \\
Baik & $23,3 \leq 27,9$ & 16 & $26,67 \%$ \\
Cukup & $\mathbf{1 8 , 7} \mathbf{2 3 , 3}$ & $\mathbf{4 2}$ & $\mathbf{7 0 \%}$ \\
Buruk & $14,1 \leq 18,7$ & 2 & $3,33 \%$ \\
Sangat Buruk & $<14,1$ & 0 & $0 \%$ \\
\hline Total & & $\mathbf{6 0}$ & $\mathbf{1 0 0 \%}$ \\
\hline
\end{tabular}

Berdasarkan Tabel diatas dapat dijelaskan bahwa 60 responden untuk variabel presentation menunjukan kategori sangat baik sebanyak 0\%, kategori baik sebanyak 26,67\%, kategori cukup sebanyak 70\%, kategori buruk sebanyak 3,33\% dan kategori sangat buruk $0 \%$. Berdasarkan klasifikasi skor persentase tertinggi berada pada rentang 18,7 $\leq 23,3$ dengan persentase $61,67 \%$ yang menunjukan kategori cukup.

Tabel 4. Distribusi Frekuensi Indikator Well Cooked

\begin{tabular}{|c|c|c|c|}
\hline Kategori & Skor & Frekuensi & Persentase (\%) \\
\hline Sangat Baik & $\geq 31,95$ & 0 & $0 \%$ \\
\hline Baik & $26,65 \leq 31,95$ & 32 & $53,33 \%$ \\
\hline Cukup & $21,35 \leq 26,65$ & 26 & $43,33 \%$ \\
\hline Buruk & $16,05 \leq 21,35$ & 2 & $3,33 \%$ \\
\hline Sangat Buruk & $<16,05$ & 0 & $0 \%$ \\
\hline \multicolumn{2}{|c|}{ Total } & 60 & $100 \%$ \\
\hline
\end{tabular}

Berdasarkan Tabel diatas dapat dijelaskan bahwa 60 responden untuk variabel wellcooked menunjukan kategori sangat baik sebanyak $0 \%$, kategori baik sebanyak 53,33\%, kategori cukup sebanyak 43,33\%, kategori buruk sebanyak 3,33\% dan kategori sangat buruk $0 \%$. Berdasarkan klasifikasi skor persentase tertinggi berada pada rentang $26,65 \leq 31,95$ dengan persentase $53,33 \%$ yang menunjukan kategori baik. 
Jurnal Bosaparis: Pendidikan Kesejahteraan Keluarga

Volume 11, Nomor 1, Maret 2020

Tabel 5. Distribusi Frekuensi Indikator Variety of Food

\begin{tabular}{cccc}
\hline Kategori & Skor & Frekuensi & Persentase (\%) \\
\hline Sangat Baik & $\geq 9$ & 26 & $43,33 \%$ \\
Baik & $\mathbf{7}$ & $\mathbf{3 2}$ & $\mathbf{5 3 , 3 3 \%}$ \\
Cukup & $5 \leq 7$ & 2 & $3,33 \%$ \\
Buruk & $3 \leq 5$ & 0 & $0 \%$ \\
Sangat Buruk & $<3$ & 0 & $0 \%$ \\
\hline Total & & $\mathbf{6 0}$ & $\mathbf{1 0 0 \%}$ \\
\hline
\end{tabular}

Berdasarkan Tabel diatas dapat dijelaskan bahwa 60 responden untuk variabel variety of food menunjukan kategori sangat baik sebanyak $43,33 \%$, kategori baik sebanyak $53,33 \%$, kategori cukup sebanyak 3,33\%, kategori buruk sebanyak $0 \%$ dan kategori sangat buruk $0 \%$. Berdasarkan klasifikasi skor persentase tertinggi berada pada rentang $7 \leq 9$ dengan persentase $53,33 \%$ yang menunjukan kategori baik.

Berdasarkan hasil penelitian yang dilakukan, maka dapat disimpulkan bahwa analisis kualitas makanan karyawan yang disajikan di The Axana Hotel Padang yang dilakukan terhadap 60 responden menunjukkan baha variabel Kualitas Makanan dikategorikan cukup $60 \%$. Dapat disimpulkan bahwa kualitas makanan di The Axana Hotel Padang masuk kedalam kategori cukup. Sesuai dengan Menurut Potter dan Hotchkiss $(2012$, p.1) food quality atau kualitas makanan adalah karakteristik kualitas makanan dari makanan yang dapat diterima oleh konsumen, seperti ukuran, bentuk, warna, konsistensi, tekstur dan rasa.

\section{Simpulan dan Saran}

Secara keseluruhan Kualitas Makanan Karyawan di The Axana Hotel Padang berada pada kategori cukup dengan persentase $60 \%$ dan berada pada rentang skor $80 \leq 100$. Sedangkan berdasarkan indikator dapat dilihat berikut ini:

1. Freshness tergolong pada kategori cukup dengan persentase $53,33 \%$ dan berada pada rentang skor $32 \leq 40$

2. Presentation tergolong pada kategori cukup dengan persentase $70 \%$ dan berada pada rentang skor $18,7 \leq 23,3$.

3. Well Cooked tergolong pada kategori baik dengan persentase $53,33 \%$ dan berada pada rentang skor 26,65 $\leq 31,95$.

Variety of Food tergolong pada kategori baik dengan persentase $53,33 \%$ dan berada pada rentang skor $7 \leq 9$.

\section{Daftar Pustaka}

Margaretha, S Fiani dan Edwin japarianto. 2012. "Analisa pengaruh Food Quality \& brand image terhadap keputusan pembelian roti kecik toko roti ganep's di kota Solo”. Jurnal Manajemen Pemasaran. Vol. 4 No. 2.

Potter, NN. Dan Hotchkiss.2012. "Food Science". The AVI PublishingCompancyinc, Westport, Connecticut

Qin, H., Prybutok, V.R., and Zhao, Q.(2009). "Perceived Service Quality in Fastfood Restaurants: Emppirical evidence from China", International Journal of Quality an d Reliability Management.

Sugiyono. 2015. Metode Penelitian Kuantitatif, Kualitatif dan R\&D. Bandung: Afabeta 